\title{
Ronald Forero Álvarez, Gemma Bernadó Ferrer, Juan Felipe González Calderón y Laura Almandós Mora (Eds. académicos). La Paz: Perspectivas antiguas sobre un tema actual, Universidad de La Sabana, Universidad Nacional de Colombia, Universidad de los Andes, Chía, 2020, 328 pp. ISBN: 978-958-12-0551-6
}

\author{
Manon Ertola Urtubey \\ Universidad Nacional de La Plata, Argentina \\ mertolaurtubey@fahce.unlp.edu.ar \\ (iD https://orcid.org/0000-0001-6563-0263
}

Es ocioso destacar que los clásicos grecolatinos siguen siendo fuente de inspiración para abordar y reflexionar sobre temas actuales. La Paz: Perspectivas antiguas sobre un tema actual, editado por Forero Álvarez, Bernadó Ferrer y Almandós Mora, es un muy buen ejemplo de esto; precisamente halla en los clásicos una forma de hacer eco en nuestro presente, "un presente inestable y conflictivo, un presente en el que la muerte y la desolación se propagan como una plaga, un presente en el que la paz es un anhelo para millones de personas inmersas en numerosos conflictos alrededor del mundo" (p. 14). Es la paz el núcleo que relaciona las doce contribuciones de este volumen, que busca ni más ni menos que contribuir al "anhelo de paz universal" (p. 14). Cada uno de sus capítulos indaga sobre el desarrollo del tema de la paz en textos de la antigüedad y relaciona esa lectura con problemáticas del mundo actual. Esta doble mirada constituye en un acertado camino para inspeccionar sobre textos y autores que siguen ofreciendo su voz durante siglos.

Precedido por una introducción a cargo de los editores, el libro está estructurado en dos grandes secciones: "Consideraciones en torno a la paz" (compuesta de siete artículos) y "Caminos hacia la paz" (los restantes cinco). Cierra el volumen un índice de pasajes, un índice de nombres y un índice temático.

Inaugura el volumen David Konstan con “¿Un mundo sin guerra? La paz sin pacifistas”, donde el autor analiza detalladamente la "Oda a la Paz (1.10)" de Tibulo, que expone, según demuestra con creces, una concepción que concuerda con el programa imperial de Augusto. El recorrido de Konstan es muy amplio y pasa revista también a las fuentes griegas, como Epicuro de Diógenes de Enoanda o Aristófanes, con una mirada de conjunto que se justifica porque en todas ellas la paz se vislumbra como una mera utopía.

Le sigue "El presente es del victimario; el pasado y el futuro, de las víctimas", de William Alcides Rodríguez, dedicado al análisis lingüístico de algunos pasajes de Ilíada, con el fin de establecer una disposición temporal en relación con la manera de afrontar el conflicto bélico troyano: la memoria y el recuerdo serían recursos fundamentales en las víctimas, en tanto el victimario "cegado por su pasión, no atiende al tiempo, pasado o futuro" (p. 76). 
“¿Tiene Heráclito de Éfeso algo que decir sobre la paz?”, tercero de los capítulos, se enfoca en la filosofía. Su autora, Liliana Carolina Sánchez Castro, rastrea los términos asociados con pólemos en la obra de Heráclito, para determinar qué puede decirnos hoy este filósofo presocrático, a su parecer, "Aceptar la guerra como la alegoría del principio cósmico que da forma al mundo" (p. 91).

El cuarto capítulo, "Guerra y paz en la poesía de Virgilio", de Vicente Cristóbal, analiza un corpus variado de Virgilio, revisa su contexto y ofrece traducciones personales de los pasajes seleccionados (Égloga IV, Geórgicas, Eneida), un corpus que mostraría el vehemente deseo de paz y de concordia ciudadana.

El quinto capítulo vuelve a la elegía 1.10 de Tibulo ("La elegía 1.10 (Elogio de la paz) de Tibulo: la actualidad colombiana de un tópico") y pertenece a Jorge Enrique Rojas Otálora. Ahora, sin embargo, la intención es indagar sobre la recepción del texto latino en Colombia, convertido en un tópico dentro de los estudios humanistas.

Con el título "La vieja mentira: dulce et decorum est pro patria mori", Juan Felipe González Calderón defiende la idea de la reinterpretación del dictum horaciano dulce et decorum est pro patria mori por parte del poeta inglés Wilfred Owen en su poema "Dulce et decorum est", una reinterpretación que conlleva una modificación fundamental: mientras en Horacio el sacrificio se ve como un acto estéticamente bello, Owen considera la experiencia en el campo de batalla como algo completamente desprovisto de heroísmo, básicamente porque la muerte en batalla es anónima, aleatoria y, en un sentido fundamental, espantosa. Finalmente, con "The Peace of Augustine and Erasmus of Rotterdam", de Martin Diter, se clausura la primera sección del libro. En este caso, se explora la concepción de la paz expuesta en las obras de San Agustín y Erasmo de Rotterdam, principalmente en De Civitate Dei 19.13-19 y Querella Pacis. No deja de lado, para ello, los testimonios de griegos y romanos.

Abre la segunda sección del volumen, el capítulo titulado "El poeta arcaico como mediador en la resolución de conflictos", de Ronald Forero Álvarez. Como su título lo indica, el autor expone el modo como los poetas antiguos influían en la sociedad en pos del cese de conflictos y la tan añorada paz. Estimula la posibilidad de acudir hoy en día a estos mecanismos artísticos para enfrentar los conflictos actuales: valernos de la poesía y la música como mecanismos para resolver los conflictos internos.

"La compasión como vehículo para la reconciliación de Ayax de Sófocles", de Santiago Eslava Bejarano, se enfoca sobre la transformación psicológica de Odiseo en relación con Áyax, para destacar el papel de la compasión al final de la obra como recurso para resolver las enemistades. Relaciona, de modo más general, con la función pedagógica de la mímesis teatral y la educación de las emociones. Con "La paz de la guerra justa desde Tucídides: el conflicto interno de Corcira”, de Felipe Castañeda, se incopora la historiografía en este volumen. Este capítulo debate sobre la doctrina de la guerra justa, a partir de la descripción del conflicto interno (stásis) que sucedió en Corcira (425-424 a.C.) por parte de Tucídides en su Historia de la guerra del Peloponeso. El autor termina reflexionando sobre la idealización de la paz como justiciera.

El capítulo once, "Honor and the Negotiation of the Peace of Nicias", de Gabriel Cabral Bernardo, estudia la conexión de las políticas interestatales en la Grecia antigua con los procesos de paz, con el objetivo de discutir la importancia de la competencia por el honor y el estatus en las negociaciones por la paz, específicamente, en la llamada Paz de Nicias (421 a.C.), durante la guerra del Peloponeso. Le sigue, por último, "Pax Olympica? The Rhetoric and Ideology of the Olympic Truce", de Jacques Bromberg, un examen de la conexión de la "tregua olímpica" (ekecheiría) con la cultura atlética de la Grecia antigua, los Juegos Olímpicos actuales y la filosofía de la paz de Pierre de Coubertin.

Como queda expuesto, los textos estudiados abarcan un período amplio que va desde la Grecia arcaica, con Homero, pasando por la Antigüedad tardía con San Agustín, hasta el Renacimiento con Erasmo de Rotterdam. No faltan los autores clásicos griegos como Sófocles, Heráclito y Tucídides o los latinos Virgilio, Horacio y Tibulo. En algunos casos se abordan aspectos puntuales en torno a la paz en obras específicas, otras veces se abarca toda la producción de un mismo autor o se analizan una variedad de autores. Todas 
las investigaciones dan cuenta de un profundo conocimiento sobre los temas tratados, de un buscado rigor académico y de una actualización bibliográfica.

La obra cumple con creces con los objetivos planteados en la introducción, esto es, indagar sobre el desarrollo del tema de la paz en textos de la antigüedad y relacionar con problemáticas actuales. Brinda, entonces, un completo espectro de reflexiones en torno a la paz, que resultarán de interés tanto para filólogos y clasicistas como filósofos, historiados y estudiosos del derecho, así también como para estudiosos por fuera del ámbito académico, preocupados por los penosos avatares que nos tocan enfrentar. 